http://jmscr.igmpublication.org/home/ ISSN (e)-2347-176x ISSN (p) 2455-0450

crossref DOI: https://dx.doi.org/10.18535/jmscr/v8i2.99

\title{
Obstetric Hysterectomy (A Ray of Hope for Dying Mother)
}

\author{
Authors \\ Dr Bhagyashree ${ }^{1}$, Dr Soma Bandyopadhyay ${ }^{2}$, Dr Prachi ${ }^{3}$, Dr Shilpi Chowdhury ${ }^{4}$ \\ ${ }^{1,4}$ PGT 2nd year, Dept. of Obstetrics and Gynaecology, KMCH \\ ${ }^{2}$ Professor, Dept. of Obstetrics and Gynaecology, $\mathrm{KMCH}$ \\ ${ }^{3}$ PGT 3rd year, Dept. of Obstetrics and Gynaecology, KMCH
}

\section{Introduction}

Emergency obstetric hysterectomy is defined as the removal of uterus either after vaginal delivery or during cesarean section or during post partum period. It is a vital procedure to save the life of a mother, although it is opted as a desperate attempt when all measures fail to control catastrophic haemorrhage.

This is a trying situation for the obstetrician as on one hand it is a life saving procedure, but on the other hand it puts an end to the women's reproductive capability.

\section{Objective}

To study the incidence, risk factors and the maternal and fetal outcomes in the cases of emergency obstetric hysterectomy

\section{Methodology}

Study Design: It is a hospital based retrospective study.

Study Place: Katihar Medical College, Obst and Gynae Department

Study Period: January 2018 to December 2018

Study population: Total deliveries during this period was 11500 and 40 patients out of them underwent obstetric hysterectomy
A detailed history including gestational age, antenatal care, obstetric history and high risk factors were taken into account

\section{Result}

Total deliveries during this period was 11500 out of these 40 patients underwent obstetric hysterectomy giving an incidence of $0.35 \%$. Maximum patients belong to the age group 26- 30 years. Minimum was 21 years and maximum was 35 years. Majority of the patients who underwent obstetric hysterectomy were uneducated and unbooked.

\begin{tabular}{|c|c|}
\hline Age & No. of patients \\
\hline $21-25$ & 5 \\
\hline $26-30$ & 25 \\
\hline $31-35$ & 15 \\
\hline Total & $40 \mathrm{pts}$ \\
\hline
\end{tabular}

\section{Indication and High Risk Factors}

$\mathrm{N}=40$

Postpartum haemorrhage - 22

- Atonic PPH - 14

- Major degree of Placenta Previa - 08

Rupture uterus - 10

- Obstructed labour - 6

- Prolong Labour - 2

- Oxytocin misuse - 2 


\section{Prev LSCS with morbidly adherent placenta -} 08

\section{Fetal Outcome}

\begin{tabular}{|l|c|c|}
\hline & $\begin{array}{c}\text { No. of pts } \\
(\mathrm{N}=40)\end{array}$ & Percentage \\
\hline Live & 10 & $25 \%$ \\
\hline Intrauterine death & 18 & $45 \%$ \\
\hline Neonatal death & 12 & $30 \%$ \\
\hline
\end{tabular}

\section{Maternal Outcome}

\begin{tabular}{|l|c|c|}
\hline \multicolumn{1}{|c|}{ Morbidity factors } & $\begin{array}{c}\text { No. of Pts N= } \\
40\end{array}$ & Percentage \\
\hline $\begin{array}{l}\text { Multiple blood } \\
\text { transfusions }\end{array}$ & 25 & $62.5 \%$ \\
\hline Febrile & 6 & $15 \%$ \\
\hline Wound infection & 4 & $10 \%$ \\
\hline Shock & 3 & $7.5 \%$ \\
\hline Coagulopathy & 1 & $2.5 \%$ \\
\hline Paralytic ileus & 1 & $2.5 \%$ \\
\hline
\end{tabular}

\section{Discussion}

Obstetric hysterectomy is usually the last resort to save the life of a dying mother. The most common causes were Intractable $\mathrm{PPh}$, Ruptured Uterus and Morbidily adherent placenta

\section{Conclusion}

Obstetric hysterectomy can save many maternal lives. Fast decision and excellent surgical skill is required. Thus obstetric hysterectomy is a necessary evil in obstetrics. Although it curtails the future child bearing potential of a women yet it saves the life of a mother. Thus called" A Ray of hope for the dying Mother"

\section{Bibliography}

1. Cunnigham F. Gary, Leveno Kenneth J, Bloom Steven L, et al, Cesarean Delivery \& Peripartum Hysterectomy In: eds, williams obstetrics. $25^{\text {th }}$ ed. New York: McGraw - Hill; 2018 : 567-590.

2. Jones III Howard W, Rock John A, Bennett Kelly A, Surgical Management of obstetric complications In : Te Linde's Operative Gynaecology, $11^{\text {th }} \mathrm{ed}$, Philadelphia; Lippincott Williams \& Wilkins ; 2015 : $799-816$.
3. Bhat S, Bhave S. Obstetric Hysterectomy a life saving procedure and its complication Int Med and Dent Sci 2016; 5(I): 9961001.

4. Mukerjee S, Agarwal L. Dahiya S, Amrin S, Singh P.A. retrospective study of obstetric hysterectomy in a tertiary care hospital Int J Med Sci Public Health 2016; 5:1644-46. 